\title{
PENGARUH SERVANT LEADERSHIP TERHADAP EMPLOYEE'S ORGANIZATIONAL MEMBER PERFORMANCE (EOMP) DIMEDIASI OLEH DISIPLIN KERJA DAN DUKUNGAN ORGANISASIONAL PERSEPSIAN
}

\author{
Yuni Siswanti ${ }^{1}$, Fintya Anggri Anjasasi \\ ${ }^{1}$ UPN "Veteran” Yogyakarta, Mahasiswa Program S3 FE Universitas Islam Indonesia \\ yuni_sis2@yahoo.co.id \\ ${ }^{2}$ Alumni FEB - Manajemen, UPN “Veteran”Yogyakarta
}

\begin{abstract}
Penelitian ini bertujuan untuk mengetahui : (1) Pengaruh servant leadership terhadap employee's organizational member performance / EOMP) (H1), (2) pengaruh servant leadership terhadap EOMP dimediasi oleh dukungan organisasional persepsian (POS) (H2), (3) pengaruh servant leadership terhadap EOMP dimediasi oleh disiplin kerja (H3). Sampel dalam penelitian ini adalah seluruh karyawan pada PT. Pos Indonesia Cabang Wates, Kulon Progo, Yogyakarta.. Teknik uji hipotesis menggunakan analisis regresi sederhana dan analisis jalur (path analysis). Hasil penelitian ini menemukan bahwa : (1) Servant Leadership berpengaruh positif dan signifikan terhadap EOMP (Hlterdukung); (2) dukungan organisasional persepsian memediasi pengaruh servant leadership terhadap kinerja karyawan.(H2 terdukung); (3) disiplin kerja memediasi pengaruh servant leadership terhadap EOMP (H3 terdukung). Metode penelitian dengan sensus dan metode pengambilan data dengan kuesioner dan wawancara. Responden adalah semua pegawai tetap di PT. Pos Indonesia Cabang Wates, Kulon Progo, Yogyakarta,sejumlah 50 orang karyawan. Hasil penelitian ini penting untuk didiskusikan lebih lanjut bagi penelitian selanjutnya,terutama peran servant leadership terhadap peningkatan variabel kunci yang lain dalam organisasi.
\end{abstract}

Kata kunci : Servant Leadership, Disiplin Kerja, Dukungan Organisasional Persepsian, dan KinerjaKaryawan

() 2017 JBTI. All rights reserved

Article history : received 03 Ags 2017; revised 14 Ags 2017; accepted 17 Sep 2017

\section{PENDAHULUAN}

Selama lebih dari dua dekade, penelitian yang mengkaji konsep dan studi empiris mengenai kepemimpinan pelayanan (servant leadership) telah dilakukan (Spears, 1995; Ehrhart, 2004; Farling et al., 1999; Van Dierendonck, 2011; Yoshida et al., 2014). Servant leader merupakan sebuah gaya dalam kepemimpinan yang berbeda dengan gaya kepemimpinan lainnya. Menurut Greenleaf (1977), seorang servant leaderhip melibatkan kemampuan individu yang ditunjukkan dalam bentuk karakteristik: empati, mendengarkan, serta komitmen terhadap pertumbuhan personal. Di saat ini, servant leadership dipandang cukup penting dan memiliki andil dalam peningkatan kesempatan bagi pengembangan kreativitas anggota, pencapaian kualitas hubungan pemimpin-anggota yang semakin baik, dengan mengutamakan pentingnya komunikasi (Avolio et al., 2009; Greenleaf, 1977; van Dierendonck, 2011). Paris dan Peachey (2013) telah melakukan penelitian mengenai gaya ini 
dan menyatakan bahwa servant leadership cukup bernilai eksistensinya, baik di level individu maupun organisasi.

Penelitian-penelitian sebelumnya telah menguji hubungan gaya kepemimpinan ini dengan kinerja individu (Hu and Liden, 2011; Hunter et al., 2013; Kool and van Dierendonck, 2012; Mayer et al., 2008; Neubert et al., 2008; Walumbwa et al., 2010). Sayangnya, menurut Griffin et al.(2007), penelitian tersebut belum menyelidiki hubungannya dengan kinerja anggota organisasi (misalnya: perilaku individu untuk mencapai efektivitas organisasi, baik efektivitas tim maupun efektivitas individu itu sendiri). Model baru yang diperkenalkan oleh Griffin et al (2007) tersebut dipandang sebagai sebuah konstruk yang signifikan, yang disebutnya dengan istilah "model baru kinerja peran". Kinerja peran ini oleh Griffin et al.(2007) disebut employee's organizational member performance (EOMP).

Penelitian yang dilakukan Carmen Otero; Neira Concepción Varela., \& Neira Belén Bande ,(2016) menunjukkan bahwa Servant Leadership berpengaruh positif dan signifikan terhadap employee's organizational member performance (EOMP). Penelitian ini mengidentifikasi tiga (3) tingkatan perilakuyang berkontribusi terhadap efektivitas (tugas, timkerja, dan organisasi). Setiap level ada tiga bentuk kinerja, yakni profiency, penyesuaian,dan proaktif. Hasil penelitian Carmen $e t$ al.(2016) menunjukkan bahwa servant leadership manajer penjualan berhubungan positif dan signifikan dengan EOMP melalui dukungan organisasional persepsian (Perceived Organizatiuonal Support / POS).

Dukungan organisasional persepsian merupakan sebuah konstruk utama dalam teori dukungan organisasional ((Eisenberger and Stinglhamber, 2011). POS merefleksikan bagaimana organisasi memberikan respon positif terhadapkaryawan atas kontribusi yang telah mereka berikan kepada organisasi (Eisenberger et al., 1986, p. 501). Mengacu pada teori dukungan organisasional (Eisenberger \& Stinglhamber, 2011) ; dan model konseptual servant leadership (van Dierendonck's, 2011), penelitian ini meyakini bahwa iklim psikologis memediasi hubungan antara servant leadership dengan kinerja anggota/karyawan. Ketika seorang pimpinan mengaplikasikan servant leadership, karyawan akan merasakan menerima dukungan dari atasan,mereka akan lebih termotivasi untuk mengibanginya dalam bentuk kinerja yang bagus (Casimir et al., 2014; Eisenberger et al., 2001). Dukungan organisasional persepsian yang dirasakan para karyawan /anggota akan berkontribusi terhadap efektivitas organisasi yang lebih besar. Oleh karena itu dukungan organisasional persepsian (POS) memediasi hubungan antara servant leadership dengan EOMP.

Dari latar belakang tersebut di atas, penelitian ini bertujuan untuk menguji: (1) apakah ada pengaruh langsung dan signifikan servant leadership terhadap employee's organizational member performance (EOMP) pada PT. Pos Indonesia cabang Wates, Kulon Progo?; (b) apakah disiplin kerja dan dukungan organisasional persepsian memediasi pengaruh servant leadership terhadap employee's organizational member performance (EOMP) pada PT. Pos Indonesia cabang Wates, Kulon Progo?

\section{KAJIAN TEORI}

\section{A. Kepemimpinan Pelayanan (servant leadership)}

Sebuah solusi yang digagas oleh Robert Greenleaf (1970) mengenai konsep Servant Leadership yang berbasis pada kebutuhan bawahan dianggap mampu menjadi solusi dalam memecahkan beragam persoalan kepemimpinan saat ini. Menyadari tantangan-tantangan dalam kepemimpinan tersebut maka dituntut peran kreatif bagi para pemimpin organisasi dalam menyikapi persoalan. Menurut Parolini, J., Patterson, K. and Winston, B. (2009), menuturkan bahwa 
kepemimpinan yang tepat untuk dapat mewujudkan hal seperti itu adalah kepemimpinan yang mampu memberikan pelayanan kepada para pengikutnya dan institusi dimana ia bekerja, serta masyarakat sekitar dimana perusahaan beroperasi. Dalam bukunya yang berjudul Servant Leadership ( Greenleaf , 1970) menyebutkan bahwa kepemimpinan pelayanan adalah suatu kepemimpinan yang berawal dari perasaan tulus, timbul dari dalam hati yang berkehendak untuk melayani, yaitu untuk menjadi pihak pertama yang melayani. Pilihan yang berasal dari suara hati itu kemudian menghadirkan hasrat untuk menjadi pemimpin. Perbedaan manifestasi dalam pelayanan yang diberikan: (1) memastikan bahwa kebutuhan pihak lain dapat dipenuhi, yaitu menjadikan mereka sebagai orang-orang yang lebih dewasa, sehat,bebas, dan otonom, yang pada akhirnya dapat menjadi pemimpin pelayanan berikutnya. Menurut Paterrson ( 2003), rendah hati adalah kemampuan seseorang untuk menjaga keseimbangan antara kemampuan yang dimiliki serta kesadaran bahwa apa yang telah ia capai sebagai pemimpin dapat terjadi karena kemampuan dan sumbangsih dari para pengikutnya, bukan karena dirinya sendiri. Seorang pemimpin yang rendah hati memfokuskan semua perhatian dan pujian kepada para pengikutnya yang telah memberikan kontribusi kepada organisasi. Oleh karenanya servant leadership bukanlah orang yang arogan dan egois. Barbuto and Wheeler (2006) menyatakan bahwa servant leadership adalah prediktor terbaik dalamhalkualitashubungan pemimpin-anggota, dibandingkan kepemimpinan transformasional. Studi Schneider \& George's (2011) pada delapan klub organisasi nirlaba menunjukkan bahwa hubungan servant leadership dengan gaya transformasional cukup kuat, namun servant leadership menjadi prediktor terbaik dalam hal komitmen, kepuasan kerja, dan intensitas untuk tinggal dibandingkan dengan gaya transformasional.

Menurut Greenleaf (2003) terdapat sepuluh karakteristik servant leadership,yakni: mendengarkan, empat, menyelesaikan masalah, kesadaran (diri sendiri dan umum), persuasif, konseptual, pandangan visioner, stewardship (komitmen atas kepercayaan yang lain), komitmen berkenan dengan perkembangan individu,dan kemampuan membangun tim.

\section{B. Employee's Organizational Member Performance (EOMP)}

Kinerja seorang supervisor berkontribusi penting terhadap karyawannya (He \& Brown, 2013). Perilaku supervisor merupakan refleksi dari kepemimpinannya. Esensi darisebuah kepemimpinan adalah kemampuan untuk mempengaruhi (Yukl, 1998). Efektivitas kepemimpinan seorang supervisor terlihat dari kapabilitasnya dalam memotivasi anggota mencapai tujuan bersama (Chemers, 2001). Beragamstudi menunjukkan bahwa kepemimpinan berdampak terhadap kinerja anggota/karyawan, baik langsung maupun tidak langsung (MacKenzie et al., 2001). Pertanggungjawaban kinerja yang dilakukan oleh seorang individu, dalam pekerjaan disebut "work role" (Neal et al., 2012). Berdasar pada perbedaan antara tugas dengan perilaku kewargaan organisasional(OCB) yang dikembangkan oleh Borman \& Motowidlo (1993); Griffin et al. (2007) mengusulkan sebuah model baru kinerja.Model ini mengidentifikasi 3 level perilaku yang berkontribusi dalam pencapaian kinerja, yakni : kecakapan/keahlian proficiency, penyesuaian (adaptivity), dan perilaku yang proaktif / proactivity). Tiga leve lperilaku dalam pembentukan kinerja tersebut dinamakan Employee's Organizational Member Performance (EOMP). Keahlian (proficiency) mendiskripsikan perilaku karyawan yang merefleksikan tercapainya harapan dan kebutuhan dalam perannya sebagai anggota organisasi (Griffin et al., 2007). Keikutsertaan seorang karyawan dalam kepanitiaan atau menyampaikan hal-hal yang baik mengernai organisasinya kepada stakeholder,merupakan contoh perilaku proficiency (Neal et al., 2012). Konsep yang hampir sama dengan istilah kesetiaan organisasional dan moral kemasyarakatan (civic virtue) (Podsakoff et al., 2000). Menurut Griffin et al. (2007), perilaku-perilaku tersebut adalah perilaku yang seringkali diharapkan organisasi dan tidak bersifat pilihan.

Penyesuaian dalam keanggotaan organisasi (adaptability) merujuk pada tingkatan individu dalam mernghadapi,merespon, dan mendukung perubahan yang berdampak terhadapperannya bagi 
organisasi (Griffin et al., 2007).Keterampilan mempelajari atau memperoleh informasi dalam memperoleh kesesuaian ketika terjadi perubahan secara keseluruhan, adalah contoh perilaku ini.

Perilaku yang proaktif (proactivity) dalam organisasi merujuk kepada keikutsertaan karyawan dalam memulai perubahan, baik di saat ini maupun di masa yang akan datang. Menyarankan perubahan dalam prosedur administrasi ketika terjadi perubahan organsasi, merupakan contoh proactivity di tingkat organisasi. Enhart (2004)menunjukkan bukti empiris hubungan perilaku karyawan yang dipimpin oleh supervisor dengan gaya servant leadership terhadap OCB dalamstudi multilevel,bahwa servant leadership merupakan anteseden dari perilaku OCB (Organizational Citizenship Behavior /perilaku kewargaan organisasional) level unit. Bartuto dan Wheeler (2006) menemukan adanya hubungan positif antara servant leadership dengan kinerja level individu (usaha ekstra, kepuasan karyawan, dan efektivitas organisasional). Jarmillo et al.(2009) dalam studinya terhadap karyawan bagian penjualanmenemukan adanya hubungan positif signifikan (koefisien korelasi0,24) antara servant leadership dengan kinerja individu.

\section{$\mathrm{H}_{1}$ : Servant leadership berpengaruh positif dan signifikan terhadap employee's organizational member performance (EOMP) pada PT. Pos Indonesia cabang Wates, Kulon Progo.}

\section{Dukungan Organisasional Persepsian (Perceived Organizational Support /POS)}

Dalam melakukan pekerjaannya, setiap karyawan mengharapkan sesuatu yang dipandang bernilai dariorganisasi dan menjadikannya memiliki komitmen di dalamnya untuk mencapai kebutuhan emosional. Sesuatu yang bernilai dan diharapkan karyawan tersebut adalah dukungan organisasional persepsian (POS). Dukungan organisasional persepsian didefinisikan sebagai kepercayaan bahwa organisasi tempatnya bekerja, akan memberikan penghargaan dan pemeliharaan (perhatian) dalam hal kesejahteraannya atas kontribusi yang telah diberikan bagi organisasi (Eisenberger et al.,1986). Servant leadership dapat meningkatkan dukungan organisasional persepsian. Dukungan organisasional yang semakin baik dipersepsikan oleh karyawan/anggota, dapat meningkatkan kinerja individu. Peningkatan kinerja ini akibat dari proses resiprokal antara manajemen dengan karyawan dalam bentuk dukungan organisasional.

\section{$\mathrm{H}_{2}$ : Dukungan organisasional persepsian memediasi pengaruh servant leadership terhadap employee's organizational member performance (EOMP) pada PT. Pos Indonesia cabang Wates, Kulon Progo.}

\section{Disiplin Kerja}

Menurut Hasibuan (2013) kedisiplinan adalah kesadaran dan kesediaan orang mentaati semua peraturan perusahaan dan norma-norma sosial yang berlaku. Disiplin yang baik mencerminkan besarnya tanggung jawab seseorang terhadap tugas-tugas yang diberikan kepadanya. Hal ini akan mendorong gairah kerja, semangat kerja dan terwujudnya tujuan organisasi. Dalam kepemimpinan seorang pemimpin harus menyatukan berbagai keahlian, pengalaman, kepribadian,dan motivasi setiap individu yang di pimpinnya. Tapi tidak demikian dengan Servant Leadershi), yang menekankan pada kemampuan seorang pemimpin dalam memberikan pelayanan dan dari pelayanannya dapat memberikan pengaruh positif kepada anggotanya tanpa ada rasa takut atau segan. Berdasarkan penelitian dari Tri Ludi Hariyanto (2014) terdapat pengaruh positif antara servant leadership terhadap kinerja karyawan dimediasi oleh disiplin kerja.

$\mathrm{H}_{3}$ : Disiplin kerja memediasi pengaruh servant leadership terhadap employee's organizational member performance (EOMP) pada PT. Pos Indonesia cabang Wates, Kulon Progo 


\section{Model Penelitian}

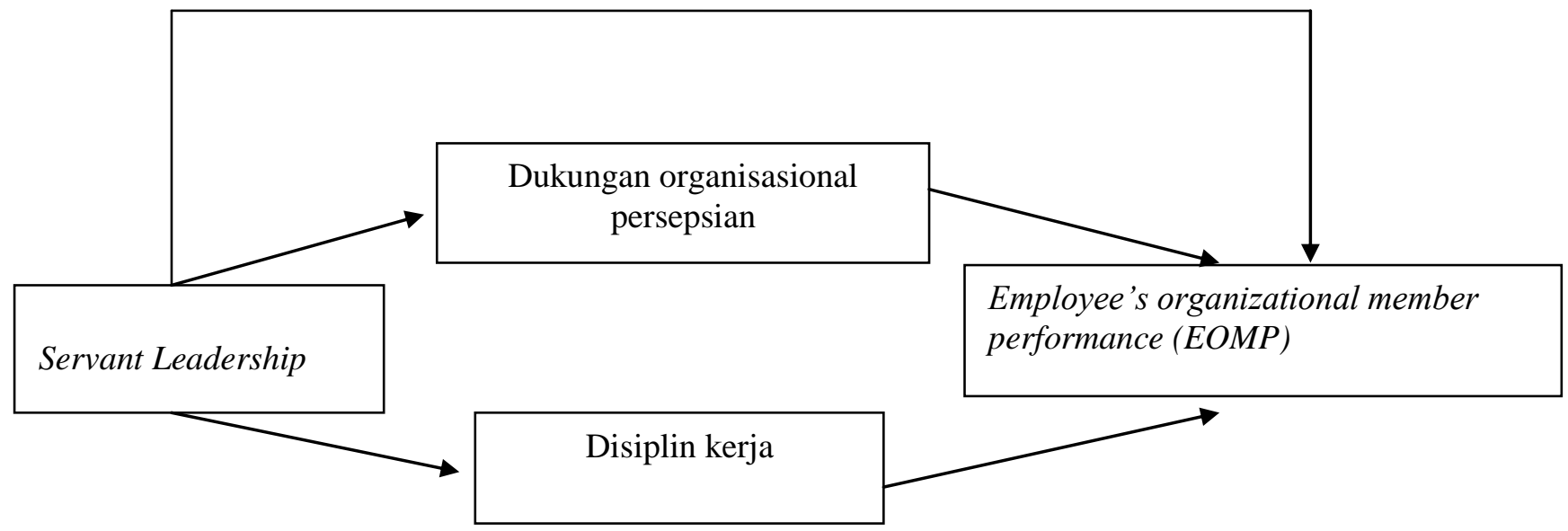

\section{METODE PENELITIAN}

A. Penelitian ini dilakukan pada PT. Pos Indonesia, Cabang Wates,Kulon Progo, Yogyakarta. Jumlah populasi sebanyak 50 orang pegawai tetap. Metode pengambilan sampelnya dengan sensus. Metode ini sesuai dengan pendapat (Arikunto, 2002) bahwa untuk penelitian yang populasinya kurang dari 100, lebih baik diambil semua. Teknik pengumpulan data dilakukan dengan penyebaran kuesioner dan wawancara kepada pihak manajemen dan beberapa pegawai di PT. Pos Indonesia, Cabang Wates, Kulon Progo.

B. Definisi Operasional dan pengukuran variabel

1) Servant leadership (Variabel Independen)

Greenleaf (1977) menyatakan bahwa servant leader adalah pemimpin yang berfokus pada orang lain dibandingkan untukdirinya sendiri dan adanya pemahaman bahwa peran kepemimpinannya adalah memberi pelayanan. Servant leader, menurut Russell and Stone (2002),dalam perannya tersebut, berusaha untuk memahami setiapanggota dan memenuhi kebutuhan mereka.

Instrumen untuk mengukur variabel servant leadership diadopsi dari Patterson (2003) dengan 7 indikator :1)Agape Love $\left(\mathrm{X}_{1.1}\right)$ : menggambarkan kasih sayang yang murni dari seseorang pemimpin; 2) Humility ( $\left.\mathrm{X}_{1.2}\right)$ : menggambarkan kerendahan hati pemimpin serta menempatkan dan menghargai prestasi orang lain lebih daripada prestasi sendiri; 3)Altruism (X1.3): pemimpin yang mengutamakan kepentingan orang lain' .4)vision (X1.4): menggambarkan sejauh mana pemimpin mencari komitmen semua anggota organisasi terhadap visi bersama dengan mengajak anggota untuk menentukan arah masa depan

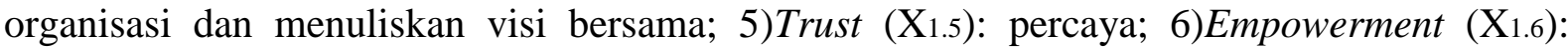
menggambarkan pemimpin yang memberdayakan masyarakat; 7)Service ( $\mathrm{X}_{1.7) \text { : }}$ menggambarkan sejauh mana pelayanan dipandang sebagai intidari kepemimpinan dan pemimpin menunjukkan perilaku pelayanannya kepada bawahan.

2) Disiplin Kerja (variabel Intervening / variabel nediasi)

Menurut Hasibuan (2013) kedisiplinan adalah kesadaran dan kesediaan orang mentaati semua peraturan perusahaan dan norma-norma sosial yang berlaku. Instrumen dan indikator disiplin kerja mengadopsi dari Mette Sandoff , Gill Widell.( 2008),diantaranya adalah :1) Disiplin terhadap aturan tertulis ; 2) Aturan perilaku disiplin kerja karyawan. 
3) Dukungan organisasional persepsian (POS) (variabel intervening / variabel mediasi)

Dukungan organisasional persepsian didefinisikan sebagai kepercayaan bahwa organisasi tempatnya bekerja, akan memberikan penghargaan dan pemeliharaan (perhatian) dalam hal kesejahteraannya atas kontribusi yang telah diberikan bagi organisasi (Eisenberger et al.,1986).

Instrumen dan indikator dari POS dalam penelitian ini mengadopsi dari Survey of Perceived Organizational Support (Eisenberger et al. 2001), sebanyak 6 item pernyataan. iInstrumen ini telah dilakukan uji validitas dan reliabilitas oleh Rhoades dan eisenberger (2002) dalam meta analisis mereka.

4) Employee's Organizational Member Performance (EOMP)

Indikator dan instrumen EOMP dalam penelitian ini mengadopsi dari Griffin et al.(2007), masing-masing meliputi: ketreampilan / keahlian (proficiency) (3 item), penyesuaian (3item), dan perilaku proaktif (3 item). Khusus untuk instrumen variabel ini diisi oleh pimpinan PT. Pos Indonesia cabang Wates, Kulon Progo, Yogyakarta.

Semua instrumen dalam pengukuran variabel, menggunakan skala Likert (5 interval). Uji instrumen menggunakan uji validitas (Confirmatory factor analysis) dan uji reliabilitas dengan melihat koefisien cronbach's alpha. Hasil uji CFA diketahui bahwa dari semua item kuesioner dinyatakan valid, hanya linstrumen dari disiplin kerja yang nilai koefisien loading factornya kurang dari 0,40 (itemtersebut tidakdimasukkan lagi dalam uji hipotesis selanjutnya). Hasil uji reliabilitas menunjukkan bahwa semua variabel yang diteliti menunjukkan koefisien cronbach;s alpha di atas 0,60 .

\section{Metode Uji Hipotesis}

Uji hipotesis dilakukan dengan regresi sederhana (uji H1) dan analisis jalur (uji H2 dan $\mathrm{H} 3$ ).

Menurut Pedhazur dalam Kerlinger (1983) dikutip oleh Widiyanto (2013), analisis jalur merupakan suatu bentuk terapan dari analisis multiregresi. Dalam analisis ini digunakan diagram jalur untuk membantu konseptualisasi masalah atau menguji hipotesis yang kompleks dan juga untuk mengetahui pengaruh langsung dan tidak langsung dari variabel-variabel bebas terhadap variabel terikat. Asumsi yang melandasi analisis jalur diantaranya adalah (Solimun 2002):

a) Hubungan antar variabel harus linear dan aditif.

b) Ukuran sampel yang memadai sebaiknya diatas 100 .

c) Pola hubungan antara variabel adalah rekursif (satu arah).

d) Data berskala interval

Skala interval merupakan skala yang membedakan kategori tertentu dengan selang atau jarak tertentu dan jarak antar kategorinya sama. Skala ini tidak memiliki nilai nol mutlak.

Adapun persamaan untuk uji $\mathrm{H} 2$ dan $\mathrm{H} 3$ dapat dirinci sebagai berikut:

Persamaan strukturalnya sebagai berikut :

Hipotesis 2 :

$\mathrm{Y}=\mathrm{a}+\mathrm{P} 1 \mathrm{X} 1$

$\mathrm{Z}_{1}=\mathrm{a}+\mathrm{P} 1 \mathrm{X} 1$

$\mathrm{Y}=\mathrm{a}+\mathrm{P} 1 \mathrm{Z1}$

$\mathrm{Y}=\mathrm{a}+\mathrm{P} 1 \mathrm{X} 1+\mathrm{P} 1 \mathrm{Z} 1$ 
Hipotesis 3 :

$\mathrm{Y}=\mathrm{a}+\mathrm{P} 1 \mathrm{X} 1$

$\mathrm{Z}_{2}=\mathrm{a}+\mathrm{P} 1 \mathrm{X} 1$

$\mathrm{Y}=\mathrm{a}+\mathrm{P} 1 \mathrm{Z}_{2}$

$\mathrm{Y}=\mathrm{a}+\mathrm{P} 1 \mathrm{X} 1+\mathrm{P} 1 \mathrm{Z}_{2}$

Keterangan:

$\mathrm{X}=$ Servant Leadership

$\mathrm{Z}_{1}=$ Dukungan organizational persepsian

$\mathrm{Z}_{2}=$ Disiplin Kerja

$\mathrm{Y}=$ Employee's Organizational Member Performance (EOMP)

P1, P2,P3 = Koefisien Pengaruh

\section{HASIL DAN PEMBAHASAN}

\section{A. Hasil Uji Diskriptif Responden}

\section{Tabel 1}

Hasil uji diskriptif responden

\begin{tabular}{|l|l|}
\hline Keterangan & Jumlah (\%) \\
\hline Jenis Kelamin: & \\
Laki-laki & 76,0 \\
Wanita & 24,0 \\
\hline Pendidikan: & \\
SMU & 44,80 \\
S1 & 5,20 \\
\hline Masa Kerja: & \\
<5 Tahun & \\
6 s/d 15 Tahun & 3,00 \\
16 s/d 20 Tahun & 30,00 \\
$\geq 21$ Tahun & 17,00 \\
& 0 \\
\hline
\end{tabular}

\section{B. Analisis Data}

\section{1) Uji Hipotesis 1}


Tabel 2

Hasil Regresi Linear Sederhana(Regresi tahap 1)

\begin{tabular}{|l|r|r|r|r|}
\hline \multicolumn{1}{|c|}{ Variabel } & \multicolumn{1}{|c|}{$\begin{array}{c}\text { Koefisien } \\
\text { (unstandardized } \\
\text { coeficient })\end{array}$} & T hitung & Sig & Keterangan \\
\hline Konstanta & 14,338 & 7,114 & 0,000 & \multicolumn{2}{|c|}{ Signifikan } \\
\hline Servant Leadership & 0,578 & 9,885 & 0,000 & Signifikan \\
\hline
\end{tabular}

Dependen Variabel: EOMP

Hasil uji H1 dengan regresi sederhana menunjukkan bahwa servant leadership berpengaruh signifikan terhadap Employee's Organizational Member Performance (EOMP) (H1 terdukung), karena koefisien signifikansinya 0,000

\section{2) Uji Hipotesis 2}

Tabel 3

Hasil Regresi tahap 2a

Pengaruh servant leadership terhadap dukungan organisasional persepsian

\begin{tabular}{|l|r|l|l|l|}
\hline \multicolumn{1}{|c|}{ Variabel } & \multicolumn{1}{|c|}{$\begin{array}{c}\text { Koefisien } \\
\text { (unstandardized } \\
\text { coeficient })\end{array}$} & T hitung & Sig & Keterangan \\
\hline Konstanta & 31,056 & 4,572 & 0,000 & \multicolumn{2}{|c|}{ Signifikan } \\
\hline Servant Leadership & 0,328 & 2,698 & 0,010 & Signifikan \\
\hline
\end{tabular}

Dependen variabel: POS

Tabel 4

Hasil Regresi tahap 3a

Pengaruh dukungan organisasional persepsian terhadap Employee's Organizational Member Performance (EOMP)

\begin{tabular}{|l|r|r|r|r|}
\hline \multicolumn{1}{|c|}{ Variabel } & \multicolumn{1}{|c|}{$\begin{array}{c}\text { Koefisien } \\
\text { (unstandardized } \\
\text { coeficient })\end{array}$} & T hitung & Sig & Keterangan \\
\hline Konstanta & 16,970 & $14,234 \quad 0,000 \quad$ Signifikan \\
\hline $\begin{array}{l}\text { Dukungan } \\
\text { organisasional } \\
\text { persepsian (POS) }\end{array}$ & 0,360 & 14,135 & 0,000 & Signifikan \\
\hline
\end{tabular}

Dependen variabel: Employee's Organizational Member Performance (EOMP) 
Tabel 5

Hasil Regresi tahap 4a

Pengaruh servant leadership dan POS terhadap EOMP

\begin{tabular}{|l|r|r|r|r|}
\hline \multicolumn{1}{|c|}{ Variabel } & \multicolumn{1}{|c|}{$\begin{array}{c}\text { Koefisien } \\
\text { (unstandardized } \\
\text { coeficient) }\end{array}$} & T hitung & Sig & Keterangan \\
\hline Konstanta & 16,970 & $14,234 \quad 0,000 \quad$ Signifikan \\
\hline Servant Leadership & 0,003 & 0,005 & 0,721 & - \\
\hline $\begin{array}{l}\text { Dukungan } \\
\text { organisasional } \\
\text { persepsian (POS) }\end{array}$ & 0,170 & 0,910 & 0,000 & Signifikan \\
\hline
\end{tabular}

Dependen variabel: Employee's Organizational Member Performance (EOMP)

Hasil uji dengan analisis jalur menunjukkan: pada tahap pertama,servant leadership berpengaruh positif dan signifikan terhdap EOMP. Tahap ke 4 diperoleh hasil yang signifikan pada POS (koefisien sign. 0,000). Hasil ini menunjukkan bahwa dukungan organisasional persepsian memediasi secara positif dan signifikan,pengaruh servant leadership terhadap EOMP, namun perannya menjadi pemediasi parsial (partially mediated variable), karena pengaruh langsungnya juga signifikan.

\section{3) Uji Hipotesis 3}

Tabel 6

Hasil Regresi tahap 2b

Pengaruh servant leadership terhadap disiplin kerja

\begin{tabular}{|l|r|l|l|l|}
\hline \multicolumn{1}{|c|}{ Variabel } & \multicolumn{1}{|c|}{$\begin{array}{c}\text { Koefisien } \\
\text { (unstandardized } \\
\text { coeficient })\end{array}$} & T hitung & Sig & Keterangan \\
\hline Konstanta & $-7,120$ & $-1,822$ & 0,075 & \\
\hline Servant Leadership & 1,642 & 14,475 & 0,000 & Signifikan \\
\hline
\end{tabular}

Dependen variabel: Disiplin Kerja 
Tabel 7

Hasil Regresi tahap 3b

Pengaruh disiplin kerja terhadap EOMP

\begin{tabular}{|l|r|r|r|r|}
\hline \multicolumn{1}{|c|}{ Variabel } & \multicolumn{1}{|c|}{$\begin{array}{c}\text { Koefisien } \\
\text { (unstandardized } \\
\text { coeficient) }\end{array}$} & $\begin{array}{c}\text { T } \\
\text { hitung }\end{array}$ & Sig & \multicolumn{2}{|c|}{ Keterangan } \\
\hline Konstanta & 16,947 & 14,204 & 0,000 & \multicolumn{2}{|c|}{ Signifikan } \\
\hline Disiplin kerja & 0,350 & 14,524 & 0,000 & \multicolumn{1}{|c|}{ Signan } \\
\hline
\end{tabular}

Dependen variabel: EOMP

Tabel 8

Hasil Regresi tahap 4b

Pengaruh servant leadership dan Disiplin kerja terhadap EOMP

\begin{tabular}{|l|r|l|l|l|}
\hline \multicolumn{1}{|c|}{ Variabel } & \multicolumn{1}{|c|}{$\begin{array}{c}\text { Koefisien } \\
\text { (unstandardize } \\
\text { d coeficient })\end{array}$} & T hitung & Sig & Keterangan \\
\hline Konstanta & 16,768 & 10,617 & 0,000 & \multicolumn{2}{|c|}{-} \\
\hline Servant Leadership & 0,018 & 0,176 & 0,861 & Signifikan \\
\hline Disiplin kerja & 0,341 & 6,048 & 0,000 & \multicolumn{2}{|c|}{0} \\
\hline
\end{tabular}

Dependen variabel: Employee's Organizational Member Performance (EOMP)

Hasil uji hipotesis 3 menunjukkan bahwa disiplin kerja memediasi secara signifikan pengaruh servant leadership terhadap EOMP (Hipotesis 3 terdukung). Hasil ini terlihat dari uji regresi ntahap $4 b$,khususnya pada koefisien signifikansi disiplin kerja menunjukkan 0,000. Disiplin kerja dalam riset ini menjadi variabel pemediasi parsial (partially mediated variable), karena pengaruh servant leadership terhadap EOMP juga signifikan.

\section{PEMBAHASAN}

Hasil analisis jalur menunjukkan bahwa ada pengaruh positif dari servant leadership secara langsung terhadap EOMP. Hasil ini memberi makna bahwa saat pemimpin mempraktikkan servant leaadership terhadap anggota-anggotanya maka mereka merasa dimuliakan sebagai pekerja/karyawqan. Mereka akan akan termotivasi untuk mencapai kinerja tinggi dan memuaskan. Kinerja yang digunakan dalam penelitian ini disebut EOMP. Kinerja individu yang berupa ketrampilan, kemampuan menyesuaikan diri, dan mampu berperilaku proaktif akan terbangun ketika pemimpinnya memiliki figur yang senang melayani, dan bukan sebaliknya. Hasil pengujian hipotesis membuktikan bahwa hipotesis 1 diterima. Hasil penelitian ini mendukung penelitian terdahulu. (Tri Ludi Herianto, Sampe adi, Choirul Saleh, 2014; Carmen Otero-Neira Concepción 
Varela-Neira Belén Bande, 2016; Mac Kenziee et al, 200; Barbuto and Wheeler, 2006; Jaramillo et al, 2009.

Servant leadership yang diaplikasikan sungguh-sungguh dalam organisasi dalam bentuk pelayanan total bagi anak buah dapat memotivasi karyawan untuk meningkatkan kinerjanya dengan lebih baik. Kinerja yang diukur dalam penelitian ini termasuk di dalamnya adalah memiliki ketrampilan/keahlian memadai, kemampuan untuk menyesuaikan diri dalam keadaan yang tidak stabil, kemampuan untuk bertindak proaktif apabila terjadi hal-hal yang tidak pada tempatnya, atau bahkan ketika organisasi mengalami poerubahan besar (perubahan status organisasi, restrukturisasi, dan sebagainya).

Hasil uji hipotesis 2 terdukung, dengan memasukkan dukungan organisasional persepsian dalam hubungan antara servant leadership dengan EOMP (kinerja level individu yang dimiliki seseorang dalam bentuk proficincy, adaptability, dan proactivity. Ketika servant leadership dipraktikkan ke dalam organisasi dengan sepenuh hati oleh pimpinan maka akan meningkat perasaan anggotanya dalam hal merasa dihargai dan mendapat dukungan organisasi. Ketika anggota merasakan adanya dukungan organisasi yang besar untuk pengembangan dirinya dan anggota lainn, maka selanjutnya akan meningkat dalam hal kinerjanya masing-masing bagi organisasi. Hasil uji hipotesis ke-2 ini mendukung riset -riset sebelumnya (Carment et al,2016).

Hasil uji hipotesis 3 yang menyatakan bahwa disiplin kerja memediasi pengaruh servant leadership terhadap EOMP dimediasi oleh disiplin kerja, terdukung. Ketika pimpinan mempraktikkan gaya pelayanan dengan antusias, anggotanya akan meresponnya dalam bentuk beragam perilaku (komitmen organisasional, kepuasan kerja, kinerja, disiplin kerja) meningkat. Perilaku karyawan yang positif, ditunjukkan dengan mematuhi peraturan dan menghindari pelanggaran kerja, jelas akan membantu dirinya sendiri dan tim untuk mencapai kinerja yang lebih baik. Bentuk kinerja (EOMP) yang dihasilkan tersebut terlihat :meningkatnya ketrampilan/keahlian diri, kemampuannya dalam menyesuaikan segala situasi, dan perilakunya yang cenderung proaktif dalam menghadapi setiap rintangan dan perubahan. Hasil riset ini mendukung penelitian-penelitian sebelumnya (Ilham Thaief, Aris Baharuddin, Priyono dan Muhamad Syafi'i Idrus, 2015; Carment et all, 2016).

\section{KESIMPULAN}

a. Servant leadership berpengaruh positif dan signifikan terhadap Employee's Organizational Member Performance (EOMP)

b. Dukungan organisasionalpersepsian memediasi secara signifikan pengaruh Servant leadership terhadap Employee's Organizational Member Performance (EOMP)

c. Disiplin kerja memediasi secara signifikan pengaruh Servant leadership terhadap Employee's Organizational Member Performance (EOMP)

\section{SARAN}

a. Pengambilan data dalam penelitian ini masih bersifat cross sectional (satu waktu), bukan longitudinal (periode waktu tertentu) yang berakibat ada kemungkinan hasilnya belum optimal. Untuk penelitian selanjutnya, akan jauh lebih bagus apabila pengambilan datanya dengan desain longitudinal.

b. Responden penelitian ini masih sangat terbatas, karena hanya mengambil objek di salah satu cabang PT.P os Indonesia Cabang Wates, Kulon Progo. Penelitian lanjutan sebaiknya mencoba 
memperluas objek (seluruh PT.Pos di satu propinsi atau seluruh Indonesia dan memperbanyak jumlah respondennya).

c. Penelitian ini masih terbatas pada responden di salah satu instansi saja, dan level analisisnya individu sehingga hasilnya tidak dapat digeneralisasikan bagi penelitian sejenis. Penelitian lanjutan sebaiknya memperluas wilayah objek dan memperhatikan faktor lain yang kemungkinan berperan besar terhadap peningkatan Employee's Organizational Member Performance (EOMP), misalnya: budaya organisasional, komitmen organisasional, kepuasan kerja, politik organisasional, keterlibtan kerja, hubungan pimpinan-bawahan, dan variabel lainnya.

d. Penelitian ini baru mencoba memasukkan variabel disiplin kerja dan dukungan organisasional persepsian sebagai mediator. Penelitian lanjutan ada baiknya untuk memasukkan variabel lain sebagai mediator, misalnya: emotional exhaustion dan sebagainya.

e. Penelitian ini baru mencoba menguji di level individu. Riset lanjutan sebaiknya dapat mencoba melakukannya di level tim/unit, karena Employee's Organizational Member Performance (EOMP), dapat dipraktikkan dalam multi level.

\section{DAFTAR PUSTAKA}

Arikunto, S., 2002, Prosedur Penelitian (Suatu PendekatanPraktek).Jakarta: Rineka Cipta.

Avolio, B.J., Walumbwa, F.O. and Weber, T.J., 2009, "Leadership: current theories, research, and future directions", Annual Review of Psychology, Vol. 60 No. 1, pp. 421-449.

Bangun, W., 2012, Manajemen Sumber Daya Manusi, Erlangga, Bandung.

Barbuto, J. E., and D. W. Wheeler., 2006, "Scale Development and Construct Clarification of Servant Leadership." Group \& Organization Management, 31(3): 300-326.

Carmen Otero-Neira Concepción Varela-Neira Belén Bande, 2016,"Supervisory servant leadership and employee's work role performance", Leadership \& Organization Development Journal, Vol. 37 (7): $860-881$.

Casimir, G., Ng, Y.N.K., Wang, Y.K. and Ooi, G., 2014, "The relationships amongst leadermember exchange, perceived organizational support, affective commitment, and in-role performance: a social-exchange perspective", Leadership \& Organization Development. Journal, Vol. 35 No. 5, pp. 366-385.

Castleman, K. R., 2004, Marketing Processing Business, Vol. 1, Ed.2, Prentice Hall, New Jersey.

David, G., 2003, Path Analysis. North Carolina State University.

Don Page dan Paul T.P. Wong, 2003, Thesis: A Conceptual Framework for Measuring Servant Leadership. Canada: Trinity Western University, Langley BC.

D.W.Wheeler \& J.E. Barbuto, 2006, Scale development and construct clarification of servant leadership [Electronic Version], Group and Organization Management, 31, 300-326.

Eisenberger R, Armeli S, Rexwinkel B, Lynch PD, Rhoades L, 2001, Reciprocation of perceived organizational support. J Appl Psychol 86:42-51.

Eisenberger R, Huntington R, Hutchison S, Sowa D., 1986, Perceived organizational support. $J$ Appl Psychol 71:500-507.

Eisenberger R, Stinglhamber F., 2011, Perceived organizational support: fostering enthusiastic and productive employees. American Psychological Association Books. 
Ehrhart, M.G., 2004, "Leadership and procedural justice climate as antecedents of unit-level organizational citizenship behavior", Personnel Psychology, Vol. 57 No. 1, pp. 61-94.

Farling, M.L., Stone, A.G. and Winston, B.E., 1999, "Servant leadership: setting the stage for empirical research", The Journal of Leadership Studies, Vol. 6 Nos 1/2, pp. 50-72.

Ghozali, I., 2012, “Aplikasi Analisis Multivariate dengan Program IBM SPSS 20” Semarang : UNDIP.

Greenleaf, R. K., 1977, Servant Leadership: A Journey into the Nature of Legitimate Power and Greatness, New York, NY: Paulist Press.

Greenleaf, R.K., 1970, The Servant as Leader, Greenleaf Center, Indianapolis, IN.

Greenleaf, R.K., 1977, Servant Leadership: A Journey into the Nature of Legitimate Power and Greatness, Paulist Press, New York, NY.

Griffin, M.A., Neal, A. and Parker, S., 2007, “A new model of work role performance: positive behavior in uncertain and interdependent contexts", Academy of Management Journal, Vol. 50 No. 2, pp. 327-347.

Hasibuan, M.S.P., 2013, Manajemen Sumber Daya Manusia. PT BumiAksara. Jakarta.

He, H. and Brown, A., 2013, “Organizational identity and organizational identification: a review of the literature and suggestions for future research", Group \& Organization Management, Vol. 38 No. 1, pp. 3-35.

Hunter, E.M., Neubert, M.J., Perry, S.J., Witt, L.A., Penney, L.M. and Weinberger, E., 2013, "Servant leaders inspire servant followers: antecedents and outcomes for employees and the organization", The Leadership Quarterly, Vol. 24 No. 2, pp. 316-331.

Jogiyanto, 2007, Metodologi Penelitian Bisnis: Salah Kaprah dan Pengalaman-pengalaman. Cetakan pertama. Yogyakarta: BPFE.

Jaramillo, F., Grisaffe, D.B., Chonko, L.B. and Roberts, J.A., 2009, "Examining the impact of servant leadership on sales force performance", Journal of Personal Selling \& Sales Management, Vol. 29 No. 4, pp. 257-275.

Kool, M. and van Dierendonck, D., 2012, "Servant leadership and commitment to change, the mediating role of justice and optimism", Journal of Organizational Change Management, Vol. 25 No. 3, pp. 422-433.

Kusnendi, 2008, Model-Model Persamaan Struktural. Bandung: Alfabeta.

MacKenzie, S.B., Podskoff, P.M. and Rich, G.A., 2001, "Transformational and transactional leadership and salesperson performance", Journal of the Academy of Marketing Science, Vol. 29 No. 2, pp. 115-135.

Mayer, D.M., Bardes, M. and Piccolo, R., 2008, "Do servant leaders help satisfy follower needs? An organizational justice perspective", European Journal of Work and Organizational Psychology, Vol. 17 No. 2, pp. 180-197.

Mette Sandoff , Gill Widell., 2008, "Coping with discipline", International Journal of Sociology and Social Policy, Vol. 28 Iss 11/12: 458 - 471.

Mette Sandoff , Gill Widell., 2007, "Consistency in employee discipline: an empirical exploration", Personnel Review, Vol. 37 Iss 1: 109-117.

Mette Sandoff, Gill Widell., 1998, "Models, styles and metaphors: understanding the management of discipline", Employee Relations, Vol. 20 Iss 4 pp. 349-364. 
Neal, A., Yeo, G., Koy, A. and Xiao, T., 2012, "Predicting the form and direction of work role performance from the Big 5 model of personality traits", Journal of Organizational Behavior, Vol. 33 No. 1, pp. 175-192.

Neubert, M.J., Kacmar, K.M., Carlson, D.S., Chonko, L.B. and Roberts, J.A., 2008, "Regulatory focus as a mediator of the influence of initiating structure and servant leadership on employee behavior", Journal of Applied Psychology, Vol. 93 No. 6, pp. 1220-1233.

Parolini, J., Patterson, K. and Winston, B., 2009, "Distinguishing between transformational and servant leadership", Leadership \& Organization Development Journal, Vol. 30 No. 3, pp. 274-291.

Parris, D.L. and Peachey, J.W., 2013, “A systematic literature review of servant leadership theory in organizational contexts", Journal of Business Ethics, Vol. 113 No. 3, pp. 377-393.

Patterson, K.A., 2003, "Servant Leadership: A Theoretical Model." Dissertation Abstract International, UMI No. 3082719.

Peterson, S.J., Galvin, B.M. and Lange, D., 2012, “CEO servant leadership: exploring executive characteristics and firm performance", Personnel Psychology, Vol. 65 No. 3, pp. 565-596.

Podsakoff, N.P., Podsakoff, P.M., MacKenzie, S.B., Mayne, T.D. and Spoelma, T.M., 2014, "Consequences of unit-level organizational citizenship behaviors: a review and recommendations for future research", Journal of Organizational Behavior, Vol. 35 pp. S87-S119.

Podsakoff, P., MacKenzie, S., Lee, J.-Y. and Podsakoff, N., 2003, "Common method biases in behavioral research: a critical review of the literature and recommended remedies", Journal of Applied Psychology, Vol. 88 No. 5, pp. 879-903.

Podsakoff, P.M., MacKenzie, S.B., Paine, J.B. and Bachrach, D.G. (2000), "Organizational citizenship behavior: critical review of the theoretical and empirical literature and suggestions for future research", Journal of Management, Vol. 26 No. 3, pp. 513-563.

Russell, R. F., and A. G. Stone., 2002, “A Review of Servant Leadership Attributes: Developing a Practical Model." Leadership \& Organization Development Journal, 23(3/4): 145-158.

Schneider, S.K. and George, W.N., 2011, "Servant leadership versus transformational leadership in voluntary service organizations", Leadership \& Organization Development Journal, Vol. 32 No. 1, pp. 60-77.

Solimun, 2002, Structural Equation ModelingLisrel dan Amos, Penerbit Universitas Negeri Malang. Malang.

Sugiyono, 2014, Metode Penelitian Kuantitatif, Kualitatif dan R\&D. Bandung : Alfabeta.

Sutrisno, E., 2013, Manajemen Sumber Daya Manusia, Edisi Pertama, Jakarta : Kencana.

Spears, L.C., 1995, Reflections on Leadership: How Robert K. Greenleaf's Theory of ServantLeadership Influenced Today's Top Management Thinkers, Wiley and Sons, New York, NY,Washington.

Thaief, I., 2015, Effect of Trainning Compensation and Work Discipline against employee (studyes in the office of PT.PLN (persero) service area and network Malang.

Tjahjono, H.K. 2015 Manajemen Sumberdaya Manusia. VSM Magister Manajemen UMY

Van Dierendonck, D., 2011, "Servant leadership: a review and synthesis", Journal of Management, Vol. 37 No. 4, pp. 1228-1261. 
Van Dierendonck, D., Stam, D., Boersma, P., de Windt, N. and Alkema, J., 2014, "Same difference? Exploring the differential mechanisms linking servant leadership and transformational leadership to follower outcomes", The Leadership Quarterly, Vol. 25 No. 3, pp. 544-562.

Widiyanto, AM, 2013, Statistika Terapan.PT Elex Media Komputindo :Jakarta.

Walumbwa, F.O., Hartnell, C.A. and Oke, A., 2010, "Servant leadership, procedural justice climate, service climate, employee attitudes, and organizational citizenship behavior: a cross-level investigation", Journal of Applied Psychology, Vol. 95 No. 3,pp. 517-529.

Wyatt, J. C, dan Spiegelhalter, D., 1991, Field Trials of Marketing Decision-Aids: Potential Problems and Solutions, Clayton, P. (ed.): Proc. 15th Symposium on Computer Applications in Medical Care, Vol 1, Ed. 2, McGraw Hill Inc, New York.

Yoshida, D.T., Sendjaya, S., Hirst, G. and Cooper, B., 2014, "Does servant leadership foster creativity and innovation? A multi-level mediation study of identification and prototypicality", Journal of Business Research, Vol. 67 No. 7, pp. 1395-1404.

Yukl, G., 1998, Leadership in Organizations, 4th ed., Prentice Hall, Englewood Cliffs, NJ. 